\title{
Restoration for State's Financial Loss as a Countermeasure against Corruption in Indonesia
}

\author{
Tommy Lyston ${ }^{1}$
}

Tarumanegara University, Indonesia. Email:1yston.tipidlior@gmail.com

Licensed:

This work is licensed under a Creative Commons Attribution 4.0 License.

Keywords:

Corruption

Restoration

Financial loss

\begin{abstract}
The word corruption has become popular among the people. It indicates that public attention to corruption is growing. Corruption in the form of damaging the state's financial management has caused financial losses of the state. It is therefore essential to conduct a study on corruption, particularly on the sentence in which the defendant is required to restore for the state's financial loss. The objective of formulating Law Number 31 Year 1999 on Corruption Eradication as amended by Law Number 20 Year 2001 is to prevent the financial use of both the State Budget $(A P B N)$ and the Regional Government Budget (APBD) from being corrupted. As a countermeasure against corruption, the restoration for state's financial loss is imposed to those committing corruption. The restoration can be applied in two ways: by requiring the defendant to pay some of money or by seizing the defendant's assets and by imposing imprisonment to the defendant.
\end{abstract}

\section{Introduction}

Today in Indonesia, people are familiar with the term corruption because the perpetrators of corruption are those who are perceived to be famous people or respected people, but it is they who cause people live in poverty (Sulista \& Zurnetti, 2011). Corruption is caused not only by one's poverty condition but also by one's driving force to live prosperously and luxuriously (Myint, 2000; Sahetapy, 1979).

Yunus Husein, in his study on "the Elements of State's Financial Losses as Corruption" in Yuntho, Sari, Limbong, Bakar, and Ilyas (2014) who mentions various transactions associated with state's financial losses. They are transaction of goods and services, transactions related to debts, and transactions related to costs and revenues.

Corruption in Indonesia has becomes a phenomenon that has damaged the elements of both the societal affairs and the state's affairs from within. For the sake of the realization of Indonesia as a corruption-free state, serious efforts and commitment from both the state's apparatus and the community's components to combat corruption. Punishment that is imposed on the perpetrators must be firm so that it makes both the perpetrators and anyone who dares to commit corruption (Mahzaniar, 2017). Therefore, this study will examine the additional penalty for a criminal act of corruption in the form of restoration of state's financial loss as countermeasure against corruption.

\section{Legal Basis}

In Indonesia, a law was enacted and formulated for the purpose of creating a just and prosperous Indonesian society based on Indonesia's politics of law that is stated in the fourth paragraph of the Preamble of the 1945 Constitution of the Republic of Indonesia (UUD 1945) proclaimed by the founders of the nation of Indonesia (Gultom, 2011).

The law enforcement on corruption in Indonesia is stated in the Law Number 20 Year 2001 regarding the Amendment of Law Number 31 Year 1999 about the Eradication of Corruption in paragraph (1) of Article 2, which says that anyone who unlawfully enriches themselves, or another person, or a corporation, from which harm to the state's finance and economy is resulted is regarded to commit a criminal act of corruption. Article 3 explains that any person with the intent to benefit himself, another person, or a corporation as well as to misuse one's authority, opportunity, or the equipment available to him because of his/her position that may harm the state's finance or the state's economy is categorized as corruption.

Prodjodikoro (1989) explains that criminal punishment is any act that is judged a crime by a ruling institution. The judgment is delegated to a person as something that is uncomfortable, as well as something that is not daily delegated (Pitta, Fung, \& Isberg, 1999). Halim (1982) uses the term crime ('delik') to translate strafbaarfeit, and defines it as a forbidden act or action and is punishable by law.

Further, criminal acts may be interpreted as an act whose perpetrator may be subject to criminal penalties (Prakoso \& Imunarso, 1987). Punishment is the result or the effect of the application of the law whose meaning 
is wider than the term crime, because it includes also the judge's decision in the field of civil law (Muladi, 2005).

\section{Theory of Penalty, Additional Penalty for a Criminal Act, and Justice}

Sudarto (1986) writes that Penalty is a synonym of the word punishment which means that punishment in a criminal sense, i.e. often by penalty or penalty by a judge. Punishment in this case has the same meaning as sentence or veroordeling. In essence, the dimension of penalty is oriented and led into a "criminal sanction." When further elaborated, "sanction" is derived and the word "sanctum", which means "affirmation" (in Dutch: betiging / berachtiging). The meaning can be positive in the form of grace / gifts, and it can be negative or punishable.

The forms of criminal sanctions vary widely, such as capital punishment, life imprisonment, imprisonment, imprisonment and fines which constitute principal penalties and penalty in the form of the revocation of certain rights, the seizure of certain goods, and the announcement of a judge's verdict which are all additional penalties (Packer, 1968). An additional penalty, according to Hamzah (2008) is a penalty that can only be imposed in addition to the principal penalty. The imposition of additional penalty is of a facultative nature but imposing additional penalty should not be without imposing the principal penalty. In other words, they have to be imposed together.

This study is focused on analyzing the restitution of state's losses in a form of some amount of money as a fine. In Article 10 of the Criminal Code (KUHP), it is explained that that penalty is a punishment imposed by paying a fine as a result of a crime committed by a person. The proceeds of this fine payment are deposited into the state treasury. A penalty is the obligation of a person who has been sentenced by a Judge / a court to pay a fine, because the defendant has committed a criminal act.

The application of both the law and the imposition of sanction are part of the enforcement of justice, so that the running system does not come out of the applicable corridor of justice. Soemitro (2004) formulates Aristotle's opinion into two parts. The first part is justice in general, while the second part is justice in particular. Justice in general means that everyone should get the same part without considering one's services. Justice in particular is justice which applies only to certain cases where the same two persons are treated unequally.

Kartohadiprodjo (2010) argues that the law aims to create a human society that live justly. The element of justice that becomes an essential element in the law is a judgment made by humans about human behavior in relation to other human beings in a social life. Thus, judging is human. What is judged is human behavior. The human behavior that is judged is a behavior that occurs in the human interactions, in the social relations among human beings (Fuller, 1969).

\section{Types of Additional Penalty in Corruption}

The objective of formulating Law Number 31 Year 1999 on Corruption Eradication renewed by Law Number 20 Year 2001 is to prevent the financial use of state budget (APBN) and regional government budget (APBD) from corruption. Corruption eradication efforts have been made, one of which is through the establishment of the Corruption Eradication Commission (KPK) stated in Law Number 30 Year 2002 about the Corruption Eradication Commission (KPK). In addition to revealing the perpetrators of their crimes, restoration for state's losses should be the next thing to do.

In Law Number 31 Year 1999 in conjunction with Law Number 20 Year 2001 on the Corruption Eradication, there are also provisions concerning additional penalties, as follows:

1. The revocation of certain rights shall be the lifting of all or part of certain rights or the deletion of all or any of the particular benefits which the Government may or may have provided to the convicted person. (Article 18 paragraph (1))

2. The seizure of certain goods includes the seizure of tangible or intangible goods or immovable goods that are used for or derived from criminal acts of corruption, including the corporations owned by the convicted person where the criminal act of corruption is committed, as well as the goods in return for the goods used in the criminal act of corruption (Article 18 paragraph (1)).

3. The announcement of the decision of the judge in Article 18 paragraph (2) says that if the convicted person does not pay the restitution as referred to in paragraph (1) letter b within a period of 1 (one) month after the decision of the court, the prosecutors who has obtained permanent legal force can seize the property of the convicted person. The seized property can also be auctioned by the prosecutor to cover the restitution. In Article 18 Paragraph (3), it says that in the event that the defendant does not have sufficient property to pay the restitution as referred to in paragraph (1) letter b, he/she shall be punished with imprisonment whose duration does not exceed the maximum limit of the principal penalty. Also, the duration of the penalty is the court's decision. 
The amount of the restoration for the state's losses, which is enjoyed by the defendant or enriches the defendant by a certain causality, which make the defendant is liable for any state's losses. In cases of corruption, money for restitution and Confiscated Cash is different.

A strict definition for these two terms need to be made, because their current definition often lead to polemics. Therefore, among government agencies must have the same understanding on the definition between money for restitution and confiscated money, moreover both go to the same depositing destination, namely to the State treasury (Indriyanto, 2007).

\section{Countermeasures of Corruption}

Based on the two definitions of state's losses according to Article 2 paragraph (1) of Law Number 31 Year 1999 and Article 1 paragraph (22) of Law Number 1 Year 2004, it can be concluded that there are two types of state's losses. The first is the state's losses that are real or tangible and the amounts and the state's losses can inevitably harm state's finances.

In accordance with the provisions of legislation, seizure and confiscation of objects and property of a convicted person shall be preceded by a crime allegation directly related to the objects or goods (Santosa, 2010).

The legal concept of confiscation under Indonesian criminal law is the expropriation of a convicted person's property of a criminal offense as an additional penalty imposed by a judge together with the principal punishment as stated in Article 10, letter (b) number (2) of the Code of Criminal Law

In some cases, a Public Prosecutor charges those who do not "obtain" the wealth / profits of a criminal act of corruption based on Article 18 paragraph 1) paragraph b of Law No.31 of 1999, which, in fact, if observed results in "unproved indictment" because one the indictment cannot be proven, so that Article 191 paragraph (1) of the Criminal Procedure Code (KUHAP) can be applied.

The procedure of "confiscation" in the implementation of payments for restitution is the regime of the civil law. In the regime of criminal law, this thing is not unfamiliar, especially with the acceptance of similar mechanisms in the United Nations Convention against Corruption 2003, which has been ratified by Law no. 7 of 2006 .

\section{Conclusion}

The recovery of state's financial losses as a countermeasure against corruption due to the act of corruption defendant can be done through two alternatives. The first alternative allows for "choice" for the convicted person, whether to pay the money for restitution or not.

A one-month grace period for paying restitution means that the convicted person has the option of paying or not paying for the restitution. If the convicted person chooses not to pay the restitution, then the civic effort in the form of seizure (seizure of execution), as stated in Article 196-200 RIB, may be made by the Prosecutor to make the Defendant pay the money for the restitution.

The second alternative is a "way out" if the convicted person does not have enough assets to for the restitution. In this case, the convicted person may be subject to a substitute imprisonment stipulated in the decision. The provision that says "the convict does not have sufficient property" means that based on the judgment of the prosecutor, the convicted person does not have enough property to be confiscated and auctioned in order to pay for the restitution.

\section{References}

Fuller, L. (1969). Human interaction and the law. American Journal of Jurispudence, 14(1), 1-36.

Gultom, L. (2011). Hand out legal philosophy. Jakarta: Faculty of Law Unkrisna.

Halim, A. R. (1982). Criminal law and questions and answers. Jakarta: Ghalia Indonesia.

Hamzah, A. (2008). Indonesian criminal procedure code. Jakarta: Sinar Grafika.

Indriyanto, S. A. (2007). Corruption, state apparatus policy and criminal law. Jakarta: CV Edited Media.

Kartohadiprodjo, S. (2010). Pancasila as a nation's life-session. Jakarta: Gatra Pustaka.

Mahzaniar, E. N. (2017). The dead penalty for corruption in the perspective of positive law and Islamic criminal law in Indonesia. IOSR Journal of Humanities And Social Sciences, 11(1), 76-82.

Muladi, A. B. N. (2005). Criminal law theories and policies. Bandung: Alumni.

Myint, U. (2000). Corruption: Causes, consequences and cures. Asia-Pacific Development Journal, 7(2), 33-58.

Packer, H. L. (1968). The limits of the criminal sanction. Stanford: Stanford University Press.

Pitta, D. A., Fung, H. G., \& Isberg, S. (1999). Ethical issues across cultures: Managing the differing perspectives of China and the USA. Journal of Consumer Marketing, 16(3), 240-256.

Prakoso, D., \& Imunarso, A. (1987). In the context of the criminal procedure code, the human rights of suspects and the role of psychology. Jakarta: Bina Aksara.

Prodjodikoro, W. (1989). Indonesian criminal law principles. Bandung: PT. Eresco.

Sahetapy, J. E. (1979). Kapita Selekta criminology. Bandung: Alumni.

Santosa, B. P. (2010). Institution for the management of specific crime assets. Jakarta: Paramadina Public Policy Institute. 
Soemitro, R. (2004). Principles and basis of taxation. Bandung: Refika Aditama.

Sudarto. (1986). Criminal law 1A-1B. Purwokerto: Faculty of law. Jenderal Soedirman University.

Sulista, T., \& Zurnetti, A. (2011). Criminal law: New post-reformation horizon. Jakarta: PT. Raja Grafindo Persada.

Yuntho, E., Sari, I. D. A., Limbong, J., Bakar, R., \& Ilyas, F. (2014). Application of state financial harmful elements in corruption crime officers. Jakarta: Indonesia Corruption Watch. 